\title{
Kesetaraan Gender dalam Program Keluarga Berencana di Kecamatan Wabula Kabupaten Buton
}

\author{
La Dausu' ${ }^{1}$ \\ 1Penyuluh BKKBN Sulawesi Tenggara \\ Email: ladausu1970@gmail.com
}

\begin{abstract}
Abstrak, Tujuan penelitin ini adalah untuk mengkaji keterlibatan gender dalam program keluarga berencana. Wacana yang lazim terjadi bahwa terdapat perbedaan perilaku antara laki-laki dan perempuan, sehingga peran-peran strategis dalam program ini seringkali terjadi ketimpangan peran gender didalamnya. Penelitian yang digunakan adalah penelitian Deskriptif Kualitatif, dilakukan dengan cara pengamatan langsung dan diberikan daftar pertanyaan atau kuesioner dengan informan yang ditentukan oleh penulis. Kemudian, data yang ditemukan dari hasil wawancara dan pengamatan tersebut akan dianalisis secara Kualitatif. Hasil penelitian ini menunjukkan bahwa program KB yang dilakukan di Kecamatan Wabula pada kenyataannya, partisipasi wanita jauh lebih besar jumlahnya dari pada pria. Terdapat dua faktor dominan dalam rendahnya partisipasi pria/ suami dalam program KB di Kecamatan Wabula secara umu. Pertama; faktor sikap yang mewujud pada perasaan ketidaknyamanan dalam penggunaan atau mengikuti program KB bagi pria/ suami. Kedua; faktor motivasi bagi perilaku, yang berkenaan dengan motivasi seseorang atau kelompok untuk menggunakan KB.
\end{abstract}

Kata Kunci : Partisipasi Gender, Alat Kontrasepsi

\begin{abstract}
The aim of this research is to examine gender involvement in family planning programs. The common discourse is that there are differences in behavior between men and women, so that strategic roles in this program often occur gender roles inequality. The research used is descriptive qualitative research, carried out by direct observation and given a list of questions or questionnaires with the informants specified by the author. Then, the data found from the interviews and observations will be analyzed qualitatively. The results of this study indicate that the family planning program carried out in Wabula District in fact, the participation of women is far greater than that of men. There are two dominant factors in the low participation of men / husbands in family planning programs in Kecamatan Wabula in general. First; attitude factor that manifests in feelings of discomfort in using or following family planning programs for men / husbands. Second; motivational factors for behavior, relating to the motivation of a person or group to use KB.
\end{abstract}

Keywords: Gender Participation, Contraception 


\section{Pendahuluan}

Indonesia adalah negara yang luas dan memiliki sumber daya alam yang melimpah. Tetapi, kekayaan yang kita miliki tersebut tidak mengandung arti apaapa, apabila kita tidak mampu memelihara keseimbangan ekosistem. Adanya penjarahan hutan lindung dan pembukaan lahan pertanian serta perkebunan yang tidak hanya mempertimbangkan keseimbangan ekosistem telah menimbulkan implikasi negatif terhadap kondisi alam di Indonesia. Pengendalian pertumbuhan penduduk pun berkaitan erat dengan kebutuhan akan pentingnya menjaga keseimbangan ekosistem. Seperti halnya, ledakan jumlah penduduk juga membutuhkan penyiapan lahan untuk tempat tinggal. Kepadatan suatu wilayah berpengaruh besar terhadap ketersediaan lahan-lahan terbuka yang berfungsi untuk daerah resapan air. Hal ini telah terbukti di banyak kota besar di Indonesia mengalami kebanjiran, akibat semakin menyempitnya lahan-lahan terbuka dan resapan air yang telah beralih fungsi sebagai daerah pemukiman penduduk.

Dalam kutipan buku teori-teori kependudukan yang diterjemahkan oleh Budiarto menyebutkan bahwa, seperti yang telah kita ketahui masalah penduduk sudah menjadi perhatian sejak jaman dahulu kala. Pada zaman kuno para negarawan maupun kelompok ahli sudah sering memperbincangkan tentang besarnya jumlah penduduk yang dikehendaki dan usaha yang bagaimana untuk merangsang maupun memperlambat pertumbuhan penduduk. Adapun pertimbangan yang dilakukan antara lain karena faktor politik, militer, sosial dan ekonomi. Ada teori kependudukan yang diungkapkan di dalam buku tersebut, antara lain teori kependudukan yang dipengaruhi oleh dua faktor yang sangat dominan. Pertama adalah meningkatkan pertu mbuhan penduduk terutama di negara-negara yang sedang berkembang. Hal ini menyebabkan tantangan agar para ahli lebih memahami faktor-faktor yang dapat mempengaruhi pertumbuhan penduduk. Yang kedua adalah adanya masalah-masalah yang sifatnya universal yang menyebabkan para ahli harus lebih banyak mengembangkan dan menguasai kerangka teori untuk mengkaji lebih lanjut sampai sejauh mana telah terjalin suatu hubungan antara penduduk dengan perkembangan ekonomi dan sosial (Budiarto, 2016).

Pertumbuhan penduduk yang terlalu cepat dapat mengurangi output yang akan dihasilkan oleh setiap pekerja, sehingga menekan berbagai tingkat kehidupan yang mengakibatkan perjuangan hidup pun terasa sangat sulit (Budiarto, 2016). Laju pertumbuhan penduduk seperti yang telah tercantum dalam literatur tentang teori kependudukan yang menyebutkan bahwa tingkat kematian akan naik apabila persediaan bahan makanan tidak cukup, demikian juga dengan perkawinan dini akan menyebabkan tingkat kematian akan semakin tinggi (Budiarto, 2016).

Ledakan jumlah penduduk atau baby booming yang akan terjadi di Indonesia dikhawatirkan akan meningkat tajam pada tahun 2020. Pemerintah memperkirakan pada tahun 2021 mendatang jumlah penduduk Indonesia 
akan bertambah menjadi 247,5 juta jiwa. Jumlah peningkatan penduduk yang sangat mengkhawatirkan bagi suatu negara berkembang seperti Indonesia (http://arsip.baubaupost.com).

Menurut data pemerintah Kabupaten Buton dalam angka pada tahun 2008, jumlah penduduk pada tahun 2010 mencapai 512.898 jiwa, pada tahun 2012 meningkat menjadi 515.372 jiwa dan pada tahun 2015 mengalami peningkatan yang cukup signifikan yaitu mencapai 522.936 jiwa. Berdasarkan hasil Estimasi Survei Penduduk Antar Sensus pada tahun 2015 Penduduk Kota Baubau mencapai 522.935 jiwa dengan rasio jenis kelamin sebesar 89.68, yang artinya bahwa pada setiap 100 penduduk perempuan terdapat sebanyak 89 peduduk laki-laki. Tingkat kepadatan penduduk Kabupaten Buton pada tahun 2015 mencapai 12.849 jiwa/ $\mathrm{km}^{2}$. Dengan tingkat kepadatan yang tinggi akan berdampak pada masalah-masalah sosial seperti perumahan, kesehatan dan juga tingkat kriminalitas. Berdasarkan estimasi tersebut, peneliti memusatkan penelitian di Kecamatan Wabula Kabupaten Buton untuk lebih memudahkan dalam pencarian datadata yang dibutuhkan dalam menunjang penelitian ini.

Menurut data Kecamatan Wabula dalam angka jumlah peserta KB aktif di sepanjang tahun 2018 terus mengalami peningkatan. Pada bulan Januari 2018 peserta KB aktif tercatat 54.699 peserta dan meningkat lagi pada bulan Mei yang mencapai 55.299 peserta dan terlihat peningkatannya lagi pada bulan Desember yang mencapai 55.289 peserta KB aktif. Sedangkan untuk wilayah Kecamatan
Wabula jumlah peserta KB sebagian besar di dominasi oleh partisipasi dari kaum perempuan.

Langkah antisipatif yang pertama dilakukan dalam penanggulangan peningkatan jumlah penduduk adalah dengan pengaturan jumlah peningkatan angka kelahiran. Program Keluarga Berencana (KB) menjadi garda terdepan untuk mengendalikan kelahiran terutama pada era otonomi daerah seperti sekarang ini. Ledakan jumlah penduduk ini akan berdampak luas terhadap penyediaan anggaran dan fasilitas kesehatan, pendidikan, serta ketersediaan pangan. Ledakan jumlah penduduk yang terjadi secara terus menerus juga akan memicu terjadinya kasus kemiskinan yang semakin tinggi pula. Selain itu juga berdampak terhadap pemenuhan gizi bayi serta meningkatnya angka pengangguran. Kondisi ini akan menambah beban pengeluaran keuangan daerah, jika ketersediaan anggaran tidak bisa terpenuhi akan berdampak pada kualitas sumber daya manusia. Karena jumlah penduduk yang padat akan sulit untuk memenuhi kebutuhan pokoknya, hal ini disebabkan oleh karena daya dukung anggaran dari pemerintah yang berkurang.

Pengendalian jumlah penduduk sangat penting bagi Indonesia. Mengingat ledakan pertumbuhan penduduk akan membawa implikasi atau dampak besar bagi kehidupan sosial kemasyarakatan yang tentunya akan menjadi tanggung jawab bagi pemerintah. Sebut saja, tingginya pertumbuhan angkatan kerja baru, dalam situasi perekonomian yang tumbuh sangat lambat, akan menimbulkan problem sosial 
yang pelik. Tingginya angka pengangguran akan mengakibatkan instabilitas sosial, seperti meningkatnya angka kejahatan yang juga semakin meningkat.

Dengan begitu, program KB sejatinya memerlukan adanya partisipasi bersama masyarakat sebagai bentuk aksi sosial yang dapat mensukseskan program tersebut. Seperti halnya dalam pembangunan lokalitas, peningkatan partisipasi diantaranya kelompok sasaran adalah salah satu dari maksud-maksud yang penting (Y.Slamet, 2009). Partisipasi dimaksud disini adalah adanya kesetaraan gender dimana program KB yang selalu tersemat pada perempuan saja, juga memerlukan keterlibatan kaum laki-laki dinilai sangat penting.

\section{Metode Penelitian}

Jenis penelitian ini adalah Penelitian Deskriptif Kualitatif, dilakukan dengan cara pengamatan langsung dan wawancara dengan informan yang ditentukan oleh penulis. Kemudian, data yang ditemukan dari hasil wawancara dan pengamatan tersebut akan dianalisis secara Kualitatif (Sugiyono, 2009). Analisa data pada penelitian ini menggunakan metode deskriptif kualitatif, dimana pembahasan penelitian serta hasilnya diuraikan melalui kata-kata berdasarkan data empiris yang diperoleh. Data yang diperoleh dalam penelitian ini adalah data yang bersifat kualitatif, maka analisis data yang digunakan non statistik.

\section{Hasil Penelitian dan Pembahasan}

\section{a. Profil Kecamatan Wabula Kabupaten Buton}

Kecamatan Wabula adalah salah satu kecamatan di Kabupaten Buton, Sulawesi Tenggara, Indonesia. Kabupaten Buton adalah salah satu Daerah Tingkat II di provinsi Sulawesi Tenggara, Indonesia. Kecamatan Wabula secara geografis terletak di bagian selatan garis khatulistiwa di antara $05^{\circ} 21^{\prime}-05^{\circ} 30^{\prime}$ Lintang Selatan dan di antara $122^{\circ} 29^{\prime}-122^{\circ} 42^{\prime}$ Bujur Timur dan mempunyai wilayah seluas $221,00 \mathrm{~km}^{2}$ atau 9,84\% dari total luas Kabupaten Buton, Kecamatan Wabula mempunyai wilayah yang dibagi menjadi 7 (Tujuh) Desa yaitu : Bajo Bahari, Holimombo, Koholimombana, Wabula, Wabula 1, Wasampela dan Wasuemba.

Data Penduduk menurut Umur, Pekerjaan, dan Tingkat Pendidikan Kecamatan Wabula Kabupaten Buton Tahun 2019 Dapat dilihat pada tabel di bawah ini :

\section{Data Penduduk Menurut Tingkat Umur}

Tabel 1.

Data Penduduk Menurut Tingkat Umur Tahun 2019

\begin{tabular}{|c|c|c|}
\hline No & Umur (Tahun) & Jumlah \\
\hline 1. & $0-12$ & 110 \\
\hline 2. & $12-20$ & 89 \\
\hline 3. & $20-25$ & 125 \\
\hline 4. & $32-35$ & 49 \\
\hline 5. & $45-60$ & 45 \\
\hline 6. & 60 Keatas & 180 \\
\hline \multicolumn{2}{|c|}{ Sumber : Data Kecamatan Wabula Tahun 2019 } \\
\hline
\end{tabular}


2. Data Penduduk Menurut Tingkat Pekerjaan

\section{Tabel 2}

Data Penduduk Menurut Tingkat Pekerjaan Tahun 2019

\begin{tabular}{|c|l|c|}
\hline No & \multicolumn{1}{|c|}{ Pekerjaan } & Jumlah \\
\hline 1. & Nelayan & 50 \\
\hline 2. & Petani & 30 \\
\hline 3. & PNS & 25 \\
\hline 4. & Karyawan Swasta & 49 \\
\hline 5. & Berkebun & 25 \\
\hline 6. & Pedagang & 39 \\
\hline 7. & Buruh Bangunan & 40 \\
\hline 8. & Lain-Lain & 89 \\
\hline \multicolumn{2}{|c|}{ Sumber : Data Kecamatan Wabula Tahun 2019 } \\
\hline
\end{tabular}

3. Data Penduduk Menurut Tingkat Pendidikan

Tabel 3

Data Penduduk Menurut Tingkat Pendidikan Tahun 2019

\begin{tabular}{|l|l|c|}
\hline No & \multicolumn{1}{|c|}{ Pendidikan } & $\begin{array}{c}\text { Jumla } \\
\text { h }\end{array}$ \\
\hline 1. & Tamat SD & 100 \\
\hline 2. & Tamat SLTP & 67 \\
\hline 3. & Tamat SLTA & 50 \\
\hline 4. & Tamat DIII, D1V, S1, S2 & 49 \\
\hline \multicolumn{2}{|c|}{ Sumber : Data Kecamatan Wabula Tahun 2019} \\
\hline
\end{tabular}

\section{b. Kesetaraan Gender dalam Program Keluarga Berencana}

Pada konferensi internasional tentang kependudukan dan pembangunan (ICPD Kairo, 1994) disepakati perubahan paradigma dari pendekatan pengendalian populasi dan penurunan fertilitas menjadi lebih kearah pendekatan kesehatan reproduksi dan kesetaraan gender (BKKBN, 2003). Salah satu masalah yang menonjol adalah rendahnya partisipasi pria dalam pelaksanaan program KB baik dalam praktik $\mathrm{KB}$, mendukung istri dalam penggunaan kontrasepsi, sebagai motivator atau promotor dan merencanakan jumlah anak (BKKBN, 2000).

Faktor-faktor yang menyebabkan rendahnya kesertaan KB pria antara lain: (1) Kondisi lingkungan sosial, budaya, masyarakat dan keluarga yang masih menganggap partisipasi pria belum atau tidak penting dilakukan. (2) Pengetahuan dan kesadaran pria dan keluarga dalam ber $\mathrm{KB}$ rendah. (3) Keterbatasan penerimaan dan aksesibilitas (keterjangkauan) pelayanan kontrasepsi pria. (4) Adanya anggapan, kebiasaan serta persepsi dan pemikiran yang salah yang masih cenderung menyerahkan tanggung jawab KB sepenuhnya kepada para istri atau perempuan.

Disadari bahwa keterlibatan gender utamnya dukungan laki-laki dalam program keluarga berencana memiliki peran yang cukup penting. Termasuk di komunitas masyarakat kecamatan wabula, dimana budaya paternalistik yang cukup kuat membuat dukungan laki-laki atau kepala keluarga menjadi penting dalam suksesnya pelaksanaan program KB. Berbagai kegiatan untuk mendukung hal ini telah banyak dilakukan oleh BKKBN yang dibantu dengan penyuluh lapangan untuk meningkatkan partisipasi pria dalam berKB dengan bantuan kondom gratis, pembentukan kelompok KB pria di tingkat desa, penyuluhan, tersedia tenaga penyuluh lapangan keluarga berencana ditiap-tiap desa dan lain-lain, namun disadari bahwa partisipasi pria masih tergolong rendah.

Disisi lain, bentuk partisipasi gender dalam hal ini pria/suami dalam KB dapat 
dilakukan secara langsung dan tidak langsung. Kondisi ini dapat diterjemahkan bahwa partisipasi pria/suami secara langsung (sebagai peserta KB) adalah pria/suami menggunakan salah satu cara atau metode pencegahan kehamilan, seperti kondom, vasektomi (kontap pria), serta KB alamiah yang melibatkan pria/suami (metode sanggama terputus dan metode pantang berkala). Sedangkan keterlibatan pria secara tidak langsung misalnya pria memiliki sikap yang lebih positif dan membuat keputusan yag lebih baik berdasarkan sikap dan persepsi, serta pengetahuan yang dimilikinya (Muhatiah. $R, 2012)$.

Hanya saja dalam penelusuran peneliti dalam partisipasi gender pada program KB di Kecamatan Wabula, diperhadapkan pada dua cara berpikir masyarakat yang dirasa dapat memberikan efek psikologis yang tidak sepenuhnya mendukung program KB di Kecamatan Wabula. Cara berpikir ini adalah bahwa masyarakat khususnya kaum pria/suami menganggap bahwa penggunaan alat kontrasepsi (misalnya: kondom) cukup menggangu dan tidak nyama, sedangkan memiliki banyak anak (meski tanpa pengaturan jarak) dianggap oleh sebagian besar masyarakat sebagai rejeki. Konsep program KB pada dasarnya adalah pengetahuan, sehingga sejatinya program ini mampu memberikan pemahaman kepada masyarakat dan tidak dilihat sebagai perintah bagi masyarakat. Pengetahuan inilah yang kemudian diharapkan dapat menstimulus partisipasi pria/ suami dalam program KB yang dilaksanakan.
Sejalan dengan hal ini, Muhatiah (2012) juga menjelaskan bahwa selain sebagai peserta $\mathrm{KB}$, suami juga dapat berperan sebagai motivator, yang dapat berperan aktif memberikan motivasi kepada anggota keluarga atau saudaranya yang sudah berkeluarga dan masyarakat disekitarnya untuk menjadi peserta $\mathrm{KB}$, dengan menggunakan salah satu kontrasepsi.

Peran gender dalam program KB memang dianggap penting, dalam penelitian tentang Isu Gender dalam Program Keluarga Berencana yang dilakukan oleh Bunyamin (2014) yang menjelaskan salah satu issue yang berkembangan terkait peran serta gender secara setara ini adalah disebabkan oleh kurangnya pengembangan metode kontrasepsi pria, Yang mengakibatkan terbatasnya jenis/metode Kontrasepsi pria; informasi tentang peran suami Dalam $\mathrm{KB} / \mathrm{KR}$ masih kurang yang mengakibatkan pengetahuan suami tentang metode $\mathrm{KB}$ pria dan kesehatan reproduksi relatif rendah; terbatasnya tempat pelayanan $\mathrm{KB} / \mathrm{KR}$ bagi kaum pria; suami cenderung tidak merasa bersalah dalam ketidakpuasan hubungan seksual dan infertilitas; rendahnya kesadaran suami tentang pencegahan PMS, IMS dan HIV/ AIDS; rendahnya keterlibatan suami dalam pemeliharaan kelangsungan hidup ibu, bayi dan anak serta keterbatasan informasi bagi lakilaki/suami tentang pemeliharaan kelangsungan hidup ibu, bayi dan anak (Bunyamin, 2014).

Pada penelusuran data mengenai pendapat para pria/ suami dalam penggunaan alat kontrasepsi di kecamatan 
wabula, sekitar $87 \%$ dari informan yang diwawancarai mengungkapkan kekhawatiran yang sama pada penggunaan kontrasepsi (kondom) hanya saja pada pria/ suami ini tidak menolak untuk memberikan ijin kepada istri/ perempuan dalam mengikuti program KB asal merasa nyaman. Sedangkan pada sisi efektifitas program KB terhadap kemampuan mengatur jarak kelahiran pada masyarakat kelurahan wabula disimpulkan belum maksimal berjalan.

Dalam pandangan lain, bahwa para pria/ suami di komunitas masyarakat kecamatan wabula ini menganggap bahwa program KB hanya berlaku untuk membatasi angka kelahiran, namun program ini sebagai solusi permasalahan sosial di masyarakat belum diyakini memiliki efek yang baik. Bahkan pada beberapa komunitas masyarakat di beberapa desa menganggap bahwa program KB bagi laki-laki memiliki efek fisik bagi laki-laki khususnya yang berkaitan dengan vitalitas dan kejantanan.

Sejalan dengan ini, pada penelitian yang dilakukan oleh Sutinah (2017) mengungkap bahwa terdapat beberapa kendala yang menghambat partisipasi lakilaki dalam ber-KB adalah adanya kekhawatiran mengganggu kejantanan, impotensi, malu karena menjadi pergunjingan di masyarakat dan alasan ekonomi karena beranggapan bahwa vasektomi memerlukan biaya yang sangat tinggi, bahkan sejumlah laki-laki tidak mau melakukan vasektomi karena akan sulit ketika menginginkan anak lagi. Dengan pendapat seperti ini, mengakibatkan pada rendahnya partisipasi pria/ suami dalam program KB yang dilakukan di Kecamatan Wabula.

\section{Kesimpulan}

Keluarga Berencana (KB) merupakan upaya peningkatan kepedulian dan peran serta masyarakat melalui pendewasaan usia perkawinan, pengaturan kelahiran, pembinaan ketahanan keluarga, peningkatan kesejahteraan keluarga untuk mewujudkan keluarga kecil, bahagian dan sejahtera. Begitu juga program KB yang dilakukan di Kecamatan Wabula, namun untuk mencapai tujun tersebut maka kesetaraan gender dalam bentuk partisipasi pasangan suami istri sangat diharapkan. Namun pada kenyataannya, partisipasi wanita jauh lebih besar jumlahnya dari pada pria.

Terdapat dua faktor dominan dalam rendahnya partisipasi pria/ suami dalam program KB di Kecamatan Wabula secara umu. Pertama; faktor sikap yang mewujud pada perasaan ketidaknyamanan dalam penggunaan atau mengikuti program $\mathrm{KB}$ bagi pria/ suami (cotohnya: penggunaan kondom). Kedua; faktor motivasi bagi perilaku, seperti pengetahuan, sikap, keyakinan, nilai, adat istiadat (budaya), dan persepsi, berkenaan dengan motivasi seseorang atau kelompok untuk bertindak, masih kuatnya anggapan bahwa banyak anak banyak rejeki, membuat keikutsertaan pria/ suami dalam program KB tergolong rendah. Selain itu, penelitian ini juga meyakini bahwa indikator demografis juga memegang peranan dalam suksesnya program KB di masyarakat Kecamatan Wabula, dimana hal ini berkenaan dengan status sosial, umur, jenis kelamin serta 
tingkat pendidikan masyarakat.

\section{Daftar Pustaka}

Alfiah, Izmi Dzalfa. 2015. Partisipasi LakiLaki dalam Program KB (Studi Kelurahan Sragen). Skripsi. Program Studi Kesehatan Masyarakat.Fakultas Kedokteran dan Ilmu Kesehatan.UIN Syarif Hidayatullah. Jakarta.

Andriani, M. (2019). Pengarusutamaan Gender dalam Implementasi Program Keluarga Berencana di Kota Yogyakarta (Doctoral dissertation, Universitas Gadjah Mada).

BKKBN. 2014. Pedoman Penyelenggaraan Pelayanan Keluarga Berencana Dalam Jaminan Kesehatan Nasional. BKKBN. Jakarta.

Budiarto. 2016. Pertumbuhan Penduduk. Universitas Diponegoro : Semarang.

Budisantoso, S. I. (2009). Partisipasi pria dalam keluarga berencana di kecamatan Jetis kabupaten Bantul. Jurnal Promosi Kesehatan Indonesia, 4(2), 103-114.

Bunyamin, B. (2014). Isu Gender Dalam Program Keluarga Berencana. Jurnal Parallela, 1(2), 151-158.

Hartini, G. Kartasapoetra. 2010. Faktor-faktor Partisipasi Masyarakat. Universitas Diponegoro : Semarang.

Muhatiah, R. (2012). Partisipasi Pria Dalam Program Keluarga Berencana (KB). Marwah: Jurnal Perempuan, Agama dan Jender, 11(1), 1-18.

Noor, Juliansyah, 2014. Metodologi Penelitian. Kencana : Jakarta.

Notoatmojo, Soekidjo. 2010. Pendidikan dan Perilaku Kesehatan. Rineka Cipta : Jakarta

Nasaruddin Umar. 2010. Pengertian Perbedaan Gendre (Laki-Laki dan Wanita). Jaringan Kebijakan Kesehatan Indonesia : Makassar.

Slamet Yonafe. 2009. Tipe Partisipasi dan
Tujuannya. Universitas Diponegoro : Semarang

Sulistyawati, Ari. 2012. Pelayanan Keluarga Berencana. Salemba Medika : Jakarta.

Sugiyono. 2009. Metode Penelitian Kuantitatif, Kualitatif, dan RED. Alfabeta : Bandung.

Pusadan, S. (2017). Implementasi Kebijakan Perencanaan Dan Penganggaran Yang Responsif Gender Pada Badan Pemberdayaan Perempuan Dan Keluarga Berencana Daerah Provinsi Sulawesi Tengah. Katalogis, 5(2).

Putri, C. P. (2014). Kesetaraan gender dalam program keluarga berencana (KB) di Dusun Sawahan Desa Sawahan Kecamatan Mojosari Kabupaten Mojokerto. Kti D3 Kebidanan.

Riasmoko, A., Yuli Kusumawati, S. K. M., Suswardany, D. L., \& SKM, M. (2011). Faktor-Faktor Yang Berhubungan Dengan Dukungan Suami Terhadap Kepesertaan Istri Dalam Program Keluarga Berencana Di Wilayah Kerja Puskesmas Kartasura Kabupaten Sukoharjo Tahun 2011 (Doctoral dissertation, Universitas Muhammadiyah Surakarta).

Sutinah, S. (2017). Partisipasi laki-laki dalam program Keluarga Berencana di era masyarakat postmodern. Masyarakat, Kebudayaan dan Politik, 30(3), 290-299. 